\title{
Management of acute intradialytic cardiovascular complications: Updated overview (Review)
}

\author{
DELIA TIMOFTE $^{1 *}$, MARIA-DANIELA TANASESCU $^{2,3}$, DANIELA GABRIELA BALAN $^{4 *}$, \\ ADRIAN TULIN $^{5,6}$, OVIDIU STIRU ${ }^{7,8^{*}}$, ILEANA ADELA VACAROIU ${ }^{9,10}$, ANDRADA MIHAI ${ }^{11,12}$, \\ CRISTIAN CONSTANTIN POPA ${ }^{13,14}$, CRISTINA-ILEANA COSCONEL ${ }^{15}$, MIHALY ENYEDI ${ }^{5,16}$, \\ DANIELA MIRICESCU ${ }^{17}$, RALUCA IOANA PAPACOCEA ${ }^{18}$ and DORIN IONESCU ${ }^{2,3 *}$
}

${ }^{1}$ Department of Dialysis, Emergency University Hospital, 050098 Bucharest; ${ }^{2}$ Department of Medical Semiology, Discipline of Internal Medicine I and Nephrology, Faculty of Medicine, 'Carol Davila' University of Medicine and Pharmacy, 020021 Bucharest; ${ }^{3}$ Department of Nephrology, Emergency University Hospital, 050098 Bucharest; ${ }^{4}$ Discipline of Physiology,

Faculty of Dental Medicine; 5 Department of Anatomy, Faculty of Medicine, 'Carol Davila' University of Medicine and Pharmacy, 020021 Bucharest; ${ }^{6}$ Department of General Surgery, 'Prof. Dr. Agrippa Ionescu' Clinical Emergency Hospital,

011356 Bucharest; ${ }^{7}$ Department of Cardiovascular Surgery, Faculty of Medicine, 'Carol Davila' University of Medicine and Pharmacy, 020021 Bucharest; ${ }^{8}$ Department of Cardiovascular Surgery, 'Prof. Dr. C.C. Iliescu' Emergency Institute for Cardiovascular Diseases, 022322 Bucharest; ${ }^{9}$ Department of Nephrology and Dialysis,

'Sf. Ioan' Emergency Clinical Hospital, 042122 Bucharest; ${ }^{10}$ Department of Nephrology, Faculty of Medicine,

'Carol Davila' University of Medicine and Pharmacy, 020021 Bucharest; ${ }^{11}$ Discipline of Diabetes; ${ }^{12}$ Department II of

Diabetes, 'N. C. Paulescu' Institute of Diabetes, Nutrition and Metabolic Diseases, 020474 Bucharest; ${ }^{13}$ Department of

Surgery, Faculty of Medicine, 'Carol Davila' University of Medicine and Pharmacy, 020021 Bucharest; ${ }^{14}$ Department of Surgery, Emergency University Hospital, 050098 Bucharest; ${ }^{15}$ Discipline of Foreign Languages, Faculty of Dental Medicine,

'Carol Davila' University of Medicine and Pharmacy, 020021 Bucharest; ${ }^{16}$ Department of Radiology,

'Victor Babes' Private Medical Clinic, 030303 Bucharest; ${ }^{17}$ Discipline of Biochemistry,

Faculty of Dental Medicine; ${ }^{18}$ Discipline of Physiology, Faculty of Medicine,

'Carol Davila' University of Medicine and Pharmacy, 020021 Bucharest, Romania

Received October 14, 2020; Accepted November 13, 2020

DOI: $10.3892 /$ etm.2021.9713

\begin{abstract}
An increasing number of patients require renal replacement therapy through dialysis and renal transplantation. Chronic kidney disease (CKD) affects a large percentage of the world's population and has evolved into a major public health concern. Diabetes mellitus, high blood pressure and a family history of kidney failure are all major risk factors for CKD. Patients in advanced stages of CKD have varying
\end{abstract}

Correspondence to: Dr Daniela Gabriela Balan, Discipline of Physiology, Faculty of Dental Medicine, 'Carol Davila' University of Medicine and Pharmacy, 12 Dionisie Lupu, 020021 Bucharest, Romania

E-mail: gdaniela.balan@yahoo.com

*Contributed equally

Key words: chronic kidney disease, hemodialysis, intradialytic hypotension, high blood pressure, arrhythmia, unstable angina, acute coronary syndrome, sudden death degrees of cardiovascular damage. Comorbidities of these patients, include, on the one hand, hypertension, hyperlipidemia, hyperglycemia, hyperuricemia and, on the other hand, the presence of mineral-bone disorders associated with CKD and chronic inflammation, which contribute to cardiovascular involvement. Acute complications occur quite frequently during dialysis. Among these, the most important are cardiovascular complications, which influence the morbidity and mortality rates of this group of patients. Chronic hemodialysis patients manifest acute cardiovascular complications such as intradialytic hypotension, intradialytic hypertension, arrhythmias, acute coronary syndromes and sudden death. Thus, proper management is extremely important.

\section{Contents}

1. Introduction

2. Acute cardiovascular complications of hemodialysis

3. Intradialytic hypotension

4. Intradialytic hypertension

5. Arrhythmias

6. Acute coronary syndrome 
7. Sudden death

8. Conclusion

\section{Introduction}

Chronic kidney disease (CKD) represents a public health concern as it affects over 50 million people worldwide, and is more and more commonly encountered, especially due to the increased incidence of high blood pressure (HBP) and diabetes mellitus (DM). Over 1 million CKD patients require renal replacement therapy (RRT) through dialysis and renal transplantation (1). DM, HBP and a family history of kidney failure are all major risk factors for CKD (2-4). Official data in the USA reported over 661,000 patients with advanced stage CKD, out of which 468,000 receive RRT through dialysis and 193,000 have a functional kidney transplant (5-7). The acute complications occur quite frequently during dialysis, and are caused by complex mechanisms, which are insufficiently known (8). Among these, the most important are cardiovascular complications, which influence the morbidity and mortality rates in this group of patients (8).

\section{Acute cardiovascular complications of hemodialysis}

Advanced stage CKD is associated with the increased risk of cardiovascular affectation. Thus, in the case of chronic dialysis patients, cardiovascular disease is identified in a large percentage of patients. An important role in its onset, in addition to factors such as mineral bone disease and patient comorbidities (e.g., HBP, hyperlipidemia, hyperglycemia, homocysteine, hypeuricemia), is chronic inflammation (9-12).

Research particularly describe a smaller total antioxidant capacity (TAC) in healthy controls than in diabetic hemodialysis patients; oxidative stress is one of the main factors leading to the onset of CKD in this group of patients (13).

Acute intradyalitic cardiovascular complications besides chronic cardivascular affectation are identified in chronic hemodialysis patients. These are summarized in Table I and are: intradialytic hypotension (IDH), HBP, arrhythmias, acute coronary syndrome (unstable angina/myocardial infarction) and sudden death (1).

\section{Intradialytic hypotension}

IDH is quite commonly encountered. It has an impact on the quality of lives of these patients, on the cost of dialysis and is associated with mortality. There is no clear definition of IDH; two factors are taken into account in clinical practice: The decrease in systolic pressure under $90 \mathrm{mmHg}$ (14) or the symptomatic intradialytic decrease in systolic pressure by more than $20 \mathrm{mmHg}$ compared to the value from the beginning of dialysis (15). Studies have demonstrated the strong association between the decrease in systolic pressure under $90 \mathrm{mmHg}$ during dialysis in over $30 \%$ of treatments and an increase in mortality (15).

Epidemiology. IDH reporting differs according to the defining criteria. Thus, IDH episodes can vary between 5 and $30 \%$ of
Table I. Acute cardiovascular complications of hemodialysis (1).

Cardiovascular complications

1. Intradialytic hypotension

2. High blood pressure

3. Arrhythmias

4. Acute coronary syndrome (unstable angina/myocardial infarction)

5. Sudden death

all hemodialysis treatments (16-18). A study that analyzed a number of 44,801 hemodialysis treatments performed on 1,137 patients found IDH present in $75 \%$ (16).

Risk factors and physiopathological particularities. There are several groups of risk factors for IDH onset, and they concern the patient, the dialysis machine or the medical manoeuvres (iatrogenic factors). Hemodialysis patients with direct or indirect cardiovascular affectation, that is to say elderly patients undergoing dialysis for a long time, diabetic patients, patients with low arterial pressure prior to dialysis, patients with systemic infections, arrhythmias, valvulopathy, myocardial infarction, hemorrhage, or patients with hypoalbuminemia are predisposed to IDH $(16,17,19,20)$ (Fig. 1).

Dialysis parameters, such as acetate dialysis, the dialysate composition and temperature (20-22), the ultrafiltration rate and the total ultrafiltration volume (23), the rapid reduction in plasma osmolality, incorrect determination of the dry weight, antihypertensive medication before dialysis and food ingestion pre- or intradialysis can also represent risk factors for IDH onset.

IDH may occurs in the case of patients with acute hemodialysis, air embolism or allergic reaction to the dialysate $(17,18,20,24)$. Table II summarizes the factors leading to IDH.

Intradialytic ultrafiltration causes the decrease in venous return, with the subsequent decrease in cardiac flow. This phenomenon is emphasized in patients with cardiac damage in whom the ventricular allure or the myocardial contractility do not increase to compensate $(25,26)$. Several studies have shown that the optimal ultrafiltration rate is $10 \mathrm{ml} / \mathrm{kg} / \mathrm{h}$; an ultrafiltration rate higher than $13 \mathrm{ml} / \mathrm{kg} / \mathrm{h}$ is associated with an increased IDH risk and an elevation in mortality (27).

The decrease in blood volume in hemodialysis patients takes place along with peripheral vasodilation $(25,28-30)$. There are several mechanisms which may produce this phenomenon, such as the release of adenosine in response to tissue ischemia, the increase in the synthesis of the vasodilating endogenous substances (nitric oxide) and the inadequate decrease in the vasopressin plasma levels (31-37).

Clinical presentation. IDH patients can be asymptomatic or can suffer from dizziness, muscle cramps, nausea, vomiting and dyspnea at rest. Vagal symptoms such as yawning, 'sighing' or hoarseness can occur before a decrease in BP (17). 


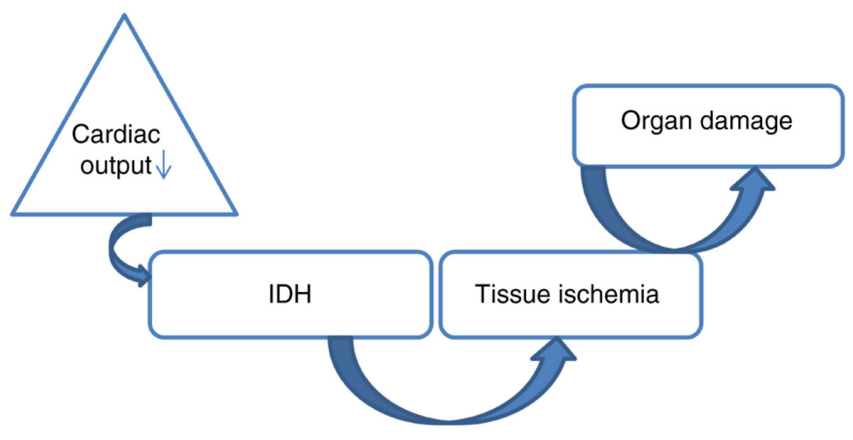

Figure 1. The impact of cardiac flow decreases in chronic hemodialysis patients (14). IDH, intradialytic hypotension.

Management. IDH management involves two aspects: Emergency treatment and the prevention of relapses.

Emergency IDH treatment. In emergency IDH treatment, the rate of ultrafiltration is decreased/stopped, the patient is placed in the Trendelenburg position, and oxygen $\left(\mathrm{O}_{2}\right)$ is administered $(38,39)$. If blood pressure does not increase following these techniques, hyperosmolar solutions or albumin is administered in bolus; these include isotonic saline solutions $(40,41)$ (Fig. 2).

IDH management to prevent relapse. The general measures for the prevention of IDH relapses involve a re-evaluation of the dry weight (42-46), avoiding intradialytic food ingestion, avoiding the administration and diminishing salt intake). Patients should also be advised regarding caffein consumption as studies have shown that 3 or more coffees daily increase the risk of a higher diastolic BP, potassium and interdialytic weight gain (IDWG). IDWG in hemodialysis patients and caffeine may alter the cardiovascular response even in healthy people (47-49).

The composition of the dialysate $(\mathrm{Ca} \geq 2.25 \mathrm{mEq} / \mathrm{l}$, $\mathrm{Mg} \geq 1.0 \mathrm{mEq} / \mathrm{l}$ and $\mathrm{Na})(50-54)$ and the dialysate temperature (low dialysate temperature increases hemodynamic stability) (55-68) must be reassessed, as complementary measures to diet adjustment.

Patients exhibiting recurrent IDH may be administered midodrine (2.5 or $5 \mathrm{mg}$ ) $15-30 \mathrm{~min}$ prior to dialysis $(63,69-73)$. Sertraline, vasopressine and carnitine can also be administered $(74,75)$.

The evaluation of the cardiac function and the treatment of anemia with erythropoiesis-stimulating agents (which increase cardiac flow) should be performed in patients with recurrent IDH. It should also be mentioned that chronic dialysis patients who are prone to recurrent IDH should have a longer hemodialysis session, and another RRT method, such as hemodiafiltration or peritoneal dialysis, respectively, should be considered (76) (Fig. 3).

\section{Intradialytic hypertension}

Intradialytic hypertension (HBP) has been defined as an increase in intradialytic systolic pressure by $\geq 10 \mathrm{mmHg}$ compared to pre-dialysis systolic pressure and it has been confirmed to be associated with increased mortality in dialysis

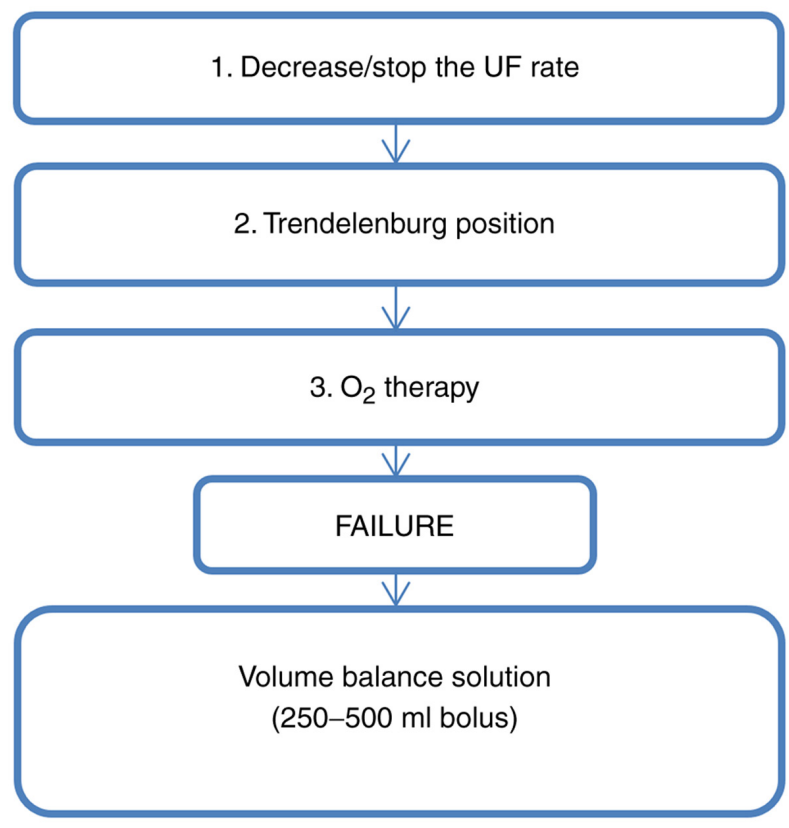

Figure 2. Intradialytic hypotension: Emergency management (38-41). UF, ultrafiltration.

patients (77). Some patients develop HBP during the last part of the dialysis session, a moment when the hydric excess has been ultrafiltered. The frequency of intradialytic HBP varies, even in the same patient, and the mechanisms are not clear; there are proofs related to the alteration of the nitric oxide/endothelin-1 balance and/or endothelial dysfunction $(78,79)$.

Epidemiology. Intradialytic HBP occurs in $10-15 \%$ of hemodialysis patients (80). The frequency of intradialytic HBP episodes varies; a study undertaken during a 6-month period showed that $90 \%$ of the patients experienced at least one HBP episode (77). The 5-year analysis of a large number of hemodialysis treatments $(n>100,000)$ showed an increase in intradialytic systolic pressure by at least $10 \mathrm{mmHg}$ in $10 \%$ of the cases; the same study concluded that the mortality risk occurs once the intradialytic pressure begins to increase, irrespective of value, and rises with a higher BP value (81). Other studies have demostrated that an increase in systolic pressure by 5 or $10 \mathrm{mmHg}$ during dialysis is associated with an increase in patient mortality (80).

Risk factors and physiopathological particularities. Studies have shown that the onset of intradialytic HBP is associated both with a volume overload between dialysis sessions and with elevated values of intradialytic pressure $(82,83)$. Patients with IDH generally have a smaller dry weight than most hemodialysis patients, have a smaller IDWG and lower pre-dialysis blood pressure (81). These patients do not have clinical signs of hyperhydration, which causes the prescription of a smaller ultrafiltration volume than the one needed, without the lowering of the arterial pressure (80). The intensive intradialytic ultrafiltration for several weeks resulted in the decrease in intradialytic pressure, emphasizing the fact that the expansion of the extracellular volume, even in the absence of clinical signs of volemic overload can mediate $\operatorname{HBP}(82,84)$. 
Table II. Intradialytic hypotension: Etiologic factors (24).

Intradialytic hypotension

Decline in circulating volume

Reaction to dialysate

Cardiac factors

Hemolysis

Defective vasoconstriction
Hemorrhage

The decrease in vascular filling rate

Excessive ultrafiltration

Myocardial infarction

Organic cardiac disease

Arrhythmias

Cardiac tamponade

Patient-related factors

Neuropathy

Hypertensive medication

Insufficient norepinephrine plasma level

Decrease in RAAS sensitivity

Splanchnic vasodilation secondary to food ingestion

Tissue ischemia

Sepsis

Anemia

Inflammation

Hemodialysis-related factors

Vasodilation secondary to acetate dialysate

Low calcium concentration in the dialysate

Complement activation

Generation of cytokines

RAAS, renin-angiotensin-aldosterone system.

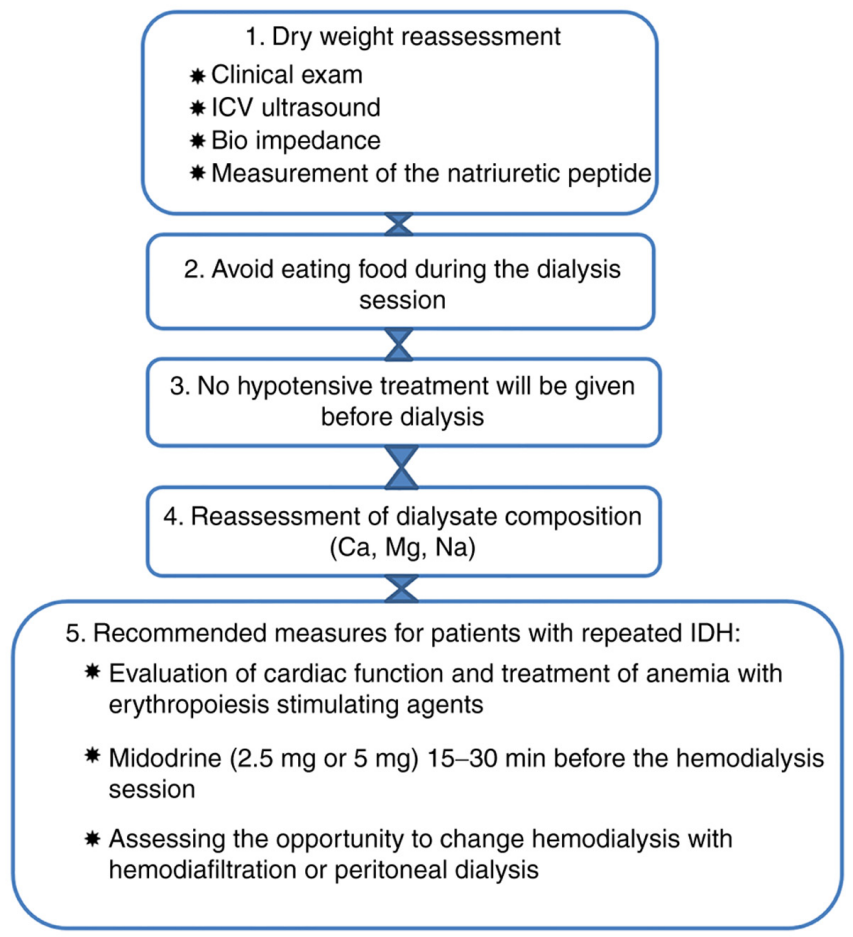

Figure 3. Recommended measures for the prevention of IDH. IDH, Intradialytic hypotension.
The intradialytic osmolar changes contribute to the arterial pressure changes, irrespective of the calculated ultrafiltration rate $(85)$.

The composition of the dialysate in establishing blood pressure values plays an important role, alongside volume overload in the chronic dialysis patients. In this respect, the clinician focuses on the sodium, potassium and calcium concentrations of the dialysate (86-88).

Sodium. A retrospective study undertaken on 113,255 hemodialysis patients over 5 years, highlighted the fact that patients with intradialytic HBP have a series of common characteristics, such as malnutrition markers, the lack of correct feeding or hydration, and lower pre-dialysis values of urea and creatinine, serum albumine, and normalized protein appearance (nPNA); they have smaller interdialysis body weight and weight gain compared to most dialysis patients (81). Sodium in the dialysate represents a key element in modulating intradialytic blood pressure values; it has been found that the sodium concentration in the dialysate is higher compared to the serum concentration of pre-dialysis sodium in intradialysis HBP patients (increased sodium gradient) (86).

Potassium. In patients who received a low-level potassium dialysate, blood pressure values were decreased after the 
first hour of the dialysis session (87); low-level potassium dialysate is also associated with rhythm disorders in dialysis patients (89).

Calcium. Calcium levels in the dialysate influence myocardial contractility and vascular tone (90). A high calcium level in the dialysate is associated with vascular hyperactivity and possibly with intradialysis $\operatorname{HBP}(88,91)$. Literature data show that intradialysis hypertension is associated with an increase in vascular resistance and less with extracellular volume overload $(78,92)$. An increase in vascular resistance is likely related to the method of dialysis per se but, on the other hand, patients with interdialysis HBP have certain common comorbidities, including ischemic coronary disease, heart failure, a history of vascular accident, and peripheral vascular disease (81).

Dialysis patients with intradialysis HBP have endothelial dysfunction, with an imbalance between vasoconstrictor substances [endotheline 1 (ET-1) and asymmetric dimethylarginine (ADMA)] and vasodilator substances [nitric oxide (NO)]. Studies have shown that ET-1 diminishes or increases during dialysis along with blood pressure $(78,93,94)$ and that patients with intradialysis HBP have high levels of ET-1 post dialysis and a low NO/ET-1 ratio $(95,96)$.

The direct involvement of the stimulation of the sympathetic nervous system in intradialysis HBP has not been demonstrated; recent research has shown that blood pressure increases during dialysis when the cardiac rhythm increases and the baroreflex activity is supressed, indicating an increased activity of the sympathetic nervous system (80).

Clinical presentation. Patients experiencing an increase in intradialysis blood pressure can be asymptomatic or can complain of headaches, profuse perspiration, thoracic discomfort, dispnea, palpitations or anxiety (78).

Management. There is no optimal therapeutic approach for HBP. Taking into account the association of HBP with volemic overload, it is necessary to accurately establish the dry weight (97).

Considering the role of ET-1 in causing IDH, carvedilol may play a beneficial role, since it is an inhibitor of ET-1 release. A pilot study, which lasted for 12 weeks, found that administration of carvedilol (50 mg twice/day) was asociated with a decreased frequency of HBP episodes from 77 to $28 \%$ during hemodialysis sessions (98). Similarly, a reduction in sodium concentration in the dialysate under the patient's serum sodium level can trigger a decrease in blood pressure values during dialysis sessions (99).

\section{Arrhythmias}

Definition. Hemodialysis patients quite frequently present with hydroelectrolytic and acid base imbalances both during and between treatment sessions, which can cause heart rhythm disorders (100).

Epidemiology. In 2013, United States Renal Data System (USDRS) reported a mortality rate of 198/1,000 patients/year, $40 \%$ of the deaths having a cardiovascular cause. Among the cardiovascular causes, 26\% were cardiac arrhythmias (101). In addition, atrial fibrillation (AFi) was the most commonly found heart abnormality in clinical practice and affected more hemodialysis patients than the general population (102), with percentages varying between $14 \%$ (103) and $27 \%$ (104). The Framingham Study reported an incidence of $0.2 \%$ per year for AFi in the general population, for 20 years. In comparison, the Afi incidence in the hemodialysis patients reaches 1.25 episod es/100 patient-year (105).

Risk factors and physiopathological particularities. Chronic hemodialysis patients have a higher risk to develop arrhythmias, taking into account the special context of the disease: The presence of certain structural and functional myocardial defects (interstitial fibrosis, decrease in coronary perfusion reserve, endothelial dysfunction), rapid hydroelectrolytic and blood pressure dynamic changes, as well as the use of certain drugs (100).

Intradialytic arrhythmias are generated by hydroelectrolytic and acid base disorders which occur quite frequently in the dialysis patients; all of these, along with the composition of the dialysate, create an 'arrhythmogenic environment' (106). On the other hand, dialysis patients present cardiovascular comorbidities, such as myocardial ischemia and secondary anemia, which increase the risk for intradialytic arrhythmias (107).

A range of acid-base $(\mathrm{pH})$ and electrolytic (especially in potassium, calcium and magnesium) changes, causing prolongation of the QT interval and associated with an increased risk of arrhythmias occur in the dialysis patients, both during and post-dialysis (108). Dialysis patients can develop atrial fibrilation during dialysis. The risk factors for the onset of Afi in these patients include ischemic coronary disease, old age, enlarged left atrium, the value of systolic pressure before the beginning of dialysis and the presence of peripheral vascular disease $(104,105)$.

Clinical presentation. The clinical picture is influenced by the rapidity of the onset of rhythm disorder, the cardiac rhythm and the pre-existing cardiovascular pathology. Patients can be totally asymptomatic when the rate of ventricular contractions is within normal limits or can suffer from cardiac failure to collapse. If the ventricular rhythm is rapid, patients complain of palpitations, precordial pain, dizziness, nausea, and syncope. Cardiorespiratory arrest and sudden cardiac death (SCD) may also occur in very severe cases (100).

Management. It is important to reduce structural myocardial changes, especially hypertrophy of the left ventricle, which predisposes to ischemia and arrhythmias. It is also necessary to optimize the dialysis parameters to ensure hemodynamic and electrolytic balance, to evaluate the drug treatment and its impact on the incidence and seriousness of malignant arrhythmias and SCD (100).

AFi treatment aims mainly to maintain the ventricular rate by administring antiarrhythmic medication or cardioversion, to improve symptomatology and to increase effort tolerance. AFi treatment also focuses on lowering the CVA risk, discontinuing the anticoagulant treatment, increasing the quality of life and the survival rate. An accepted alternative, although 
often secondary to antiarrhythmic medication is the strategy to simply control the rate of ventricular response of AFi by using node blocking agents in association with continuous anticoagulation (109).

Class 1A and 1C arrhythmic medications can ensure the rapid conversion of $\mathrm{AFi}$ to the sinus rhythm; for example, propafenone can be administered successfully both for paroxistic AFi and for the prevention of relapses. Taking into account that it is eliminated through the liver, it can be safely used to treat dialysis patients (102). As in most cases, caution is necessary when administered to patients with concomitant liver disease (110).

Digoxin is sometimes administered also in patients with $\mathrm{AFi}$ and cardiac failure. Taking into consideration that digoxin half-time is extended; this can cause arrhythmias in the presence of arrythmogenic factors such as hypopotassemia or class 1A arrhythmic medication. Digoxin toxicity causes bradycardia, different degrees of atrioventricular block, junctional tachycardia, ectopic ventricular activity and ventricular tachycardia. Oral administration of digoxin in dialysis patients at doses of $0.125 \mathrm{mg} 3$ or 4 times a week seems safe and efficient. A $0.125 \mathrm{mg} /$ day dose may easily lead to toxic levels and $0.25 \mathrm{mg} /$ day can be life threatening. For these reasons, digoxin administration in dialysis patients should be carried out with extreme care (100).

There are few studies that show that angiotensin-converting enzyme (ACE) inhibitor treatment in dialysis patients is associated with a lower number of AFi episodes as compared to this incidence in the general population.

AFi hemodialysis patients run the risk of bleeding and thrombosis (104). Because of their renal pathology, chronic hemodialysis patients have a high risk of bleeding, thus treatment with oral anticoagulants increases the risk by 3 - to 10-times in this group of patients compared to the general population (111-113). On the other hand, the rate of thromboembolic events is much higher in these patients. Randomized studies have shown that oral anticoagulant prophylaxis is more efficient than aspirin in reducing the CVA risk associated with $\mathrm{AFi}$ in dialysis patients, although it increases the risk of bleeding and/or vascular calcifications (114). Until new data become available, treatment with oral anticoagulants and monitoring are recommended in hemodialysis patients with chronic AFi (105).

Implantable cardioverter defibrillator (ICD) implantation in dialysis patients who were resuscitated after a cardiorespiratory arrest significantly improved the survival rate (the risk of death decreases by 42\%) (115). On the other hand, a meta-analysis of the existing data in the literature showed that the mortality rate in ICD dialysis patients is $2.7 \%$ higher than in non-dialysis patient (116). The use of ICD in dialysis patients has a series of adverse effects. It is associated with an increased risk of bleeding and infection. Positioning the ICD on the same side with the vascular approach is associated with a higher rate of stenosis and occlusion of the subclavian vein. Factors that should be taken into consideration in these patients include: Performing hemostasis with special care, avoiding post-implantation anticoagulation, placing of intravascular leads on the contralateral side of dialysis access and the use of high-output devices with left-sided prepectoral generator placement (116).

\section{Acute coronary syndrome}

Definition. CKD is associated with a high death risk of cardiovascular pathology (117-121). Most often patients with CKD have an acute myocardial infarction as the initial manifestation of ischemic heart disease, without previous signs of stable angina (122).

Epidemiology. Cardiovascular diseases account for about $45 \%$ of the death in dialysis patients $(123,124)$. Among these, approximately $10 \%$ are caused by ischemic coronary disease/coronary heart disease (CHD). Dialysis patients have a higher CHD incidence with a rate of death through myocardial infarction higher than the general population (125). The data reported by the 2018 Annual Data Report of the United States Renal Data System (USRDS) showed a $15.3 \%$ prevalence of acute myocardial infarction in the hemodialysis population (https://adr.usrds. org/2020/end-stage-renal-disease/8-cardiovascular-disease-inpatients-with-esrd) Similarily, in 2016, the adjusted mortality rate was 166 in 1,000 patients-year for hemodialysis patients; $37 \%$ of the deaths had cardiovascular causes, and $11 \%$ were due to myocardial infarction and CHD (125).

Risk factors and physiopathological particularities. There are several types of CHD risk factors in the dialysis patients. In this respect, CHD onset can be favored by 'traditional' risk factors or by uremia-related risk factors. The 'traditional' risk factors include: DM (54\%), low serum high-density lipoprotein (HDL) cholesterol (33\%), HBP (96\%), HVS diagnosed by electrocardiographic criteria $(22 \%)$, sedentary life style $(80 \%)$, old age (125), and smoking (126-128).

CKD is an independent CHD risk factor (129-131). Uremia and hemodialysis as treatment methods increase oxidative stress and the production of proinflammatory factors (132), and so creates a favorable envirnonment for the fast development of atherosclerosis (133-139).

Chronic hemodialysis patients exhibit the increased production of nitric oxide (NO) inihibitors, which cause vasoconstriction and $\mathrm{HBP}$ and augument the risk of acute cardiovascular events. ADMA, an endogenous NO inhibitor, is significantly elevated in chronic hemodialysis patients and is an important predictor for cardiovascular mortality in these patients (140-142). The amplification of oxidative stress in these patients represents an extra aggravating factor (143) and can be evaluated by determining the activity of certain antioxidant enzymes (144).

Hemodialysis patients present extensive vascular and valvular calcifications, associated with mineral and bone anormalities. These patients have been found to have increased phospho-calcium product, secondary hyperparathyroidism and increased calcium intake through the treatment with calcium-based phosphorus binders. In chronic hemodialysis patients, calcium is identified at the levels of vascular media and the intima, in atheroma plaque $(145,146)$. The calcification of the vascular media is associated with an increase in arterial stiffnes, but not with atherosclerosis or the narrowing of the arterial lumen. Even in the absence of atherosclerosis or luminal narrowing, coronary media calcification can cause a decrease in diastolic filling, while the peripheral medial calcification increases cardiac afterload $(145,146)$. 
Clinical presentation. Hemodialysis patients are most often asymptomatic or have atypical symptoms which can delay the diagnosis and choice of therapeutic approach $(147,148)$. Angina can occur during dialysis, and is precipitated by the exchange of fluids and by the episodes of IDH. Myocardial ischemia and the effort angina are covered in this group of patients because they are generally sedentary, or the level of their effort is very low. Patients with serious coronary lesions can suffer from acute coronary syndrome (ACS)-unstable angina, non-ST elevation myocardial infarction, or ST elevation myocardial infarction. The classic diagnostic triad (angina, increased biological markers and EKG changes) cannot be found in hemodialysis patients (147). EKG can show left ventricle hypertrophy in HD patients, which can mask the ST segment depression. The cardiac lesion markers (creatine kinase MB isoform and troponin I) can be elevated in dialysis patients in the absence of myocardial necrosis, as a reflection of cellular apoptosis or small vessel disease (149).

Management. The prognosis of CKD and ACS patients are unfavorable, in spite of the present medical therapies and the revascularization techniques (150). Platelet antiagregants in ACS patients decrease the mortality risk, although they increase minor bleeding. Thus, clopidogrel administered to non-ST-segment elevation patients to prevent relapses (CURE Trial) proved beneficial $(151,152)$. The PLATO Study (Platelet Inhibition and Patient Outcomes) showed that ticagrelor, an oral purinergic receptor inhibitor cleared by extrarenal mechanisms, reduced mortality and major cardiovascular events, being more efficient than clopidogrel in CKD and ACS patients (153). A recent meta-analysis showed that antiplatelet agents reduce the probability of myocardial infarction in CKD patients, but have unclear effects on vascular accidents and mortality and can increase the risk of bleeding (152).

Glycoprotein IIb/IIIa inhibitors or clopidogrel, in association with the standard ACS treatment, have a minimal or no effect on mortality, myocardial infarction or coronary revascularization and can heighten the risk of major bleeding in CKD and ACS patients or in patients with high-risk coronary artery intervention. Aspirin is essential in CKD and ACS patient treatment (154). The benefits of antiplatelet agent treatment are not known in CKD and ACS patients (154).

Statins decrease the risk of cardiovascular events and cardiovascular death in dialysis patients (155). The results reported in studies performed to date do not explain the impact of the treatment with statins in CKD and ACS patients (154).

The therapy of cardiovascular revascularization, including percutaneous coronary intervention (PCI) and coronary artery bypass grafting (CABG) is used also in dialysis patients. Studies have demonstrated that SCA dialysis patients treated with PCI can have a lower mortality risk compared to those patients who only receive medication (156). Comparing various strategies of coronary revascularization, dialysis patients who received $\mathrm{CABG}$ surgery have a prolonged long-time survival vs. the ones who received PCI (157-159). Several studies have aimed to ascertain whether dialysis patients benefit from aggressive SCA therapy more than from conservative therapy.

\section{Sudden death}

Definition. Sudden death refers to the sudden arrest of cardiac activity, with hemodynamic collapse, generally caused by sustained ventricular arrhythmia (ventricular tachycardia or ventricular fibrillation). These events occur in patients with preexisting cardiac diseases, particularly ischemic coronary disease (160).

Epidemiology. Data reported by DOOPS (Dialysis Outcomes and Practice Patterns) show a high SCD prevalence among hemodialysis patients in the US (33\% of all deaths) compared to other countries, such as Japon (23\%), Australia/New Zealand (19\%), and Canada (18\%) (161). Hemodialysis patients who suffered sudden cardiac arrest and were resuscitated present smaller chances of long-term survival $(8 \%)(162,163)$.

Risk factors and physiopathological particularities. Hemodialysis patients have a particularity concerning the predisposition for SCD, because of the myocardial affectation and due to the risk factors for fatal arrhythmias (164). In the general population, the main SCD physiopathologic mechanism is the rupture of atheroma plaques, with acute secondary ischemia and reduction in the left ventricle ejection fraction. The association of ventricular fibrilation causes cardiac arrest and death takes place in about $80 \%$ of cases $(165,166)$. The mechanism is different for hemodialysis patients. Thus, these patients present with arterial wall stiffening, valvular and vascular calcifications, affecting especially the vascular media, not the intima (167). A study on 1,200 patients showed that a reduction in left ventricle ejection fraction occurs in only $13 \%$ of the cases (168). On the other hand, it seems that hemodialysis patients with SCD and left ventricular hypertrophy present diastolic dysfunction. Studies show that left ventricular hypertrophy $(\mathrm{LVH})$ is a risk factor for sudden death in this group of patients (169). More than $70 \%$ of SCD patients had LVH $(170,171)$.

In chronic hemodialysis patients there is a series of factors which trigger arrhythmias: Low content calcium of the dialysate, aggressive ultrafiltration, hyperkalemia and rapid potassium elimination, especially in patients who receive hemodialysis three times a week, during the session following the longest interdialysis pause (Monday and Tuesday) (164). The use of a high bicarbonate concentration in the dialysate causes metabolic alkalosis, associated with hypocalcemia, hemodynamic instability and the elongation of the QT interval (164).

Another risk factor for SCD is the overexpression of angiotensin II. There is a range of angiotensin II mechanisms of action, such as stimulation of fibrosis and inflammation, increased activity of the sinus node and of the His-Purkinje system, alteration of $\mathrm{Ca}^{2+}, \mathrm{K}^{+}$and $\mathrm{Na}^{+}$exchange at the cell level, increased sympathetic nervous system activity, and aldosteron release (109).

Clinical presentation. SCA patients lose consciousness within seconds or minutes because of insufficient cerebral irrigation. These patients do not generally have warning symptoms or they may have unspecified signs, such as discomfort in the thorax, palpitations, dyspnea and fatigability. Ventricular 
tachyarrhythmias are the most common and are associated with cardiorespiratory arrest, both in the general population and in dialysis patients (172). Studies have shown that the indexed left ventricular mass is the most powerful predictor for ventricular arrhytmia in CKD patients (173). A study of 75 chronic hemodialysis patients who had a portable defibrillator showed that $79 \%$ of cardiac arrests were caused by ventricular tachycardia or ventricular fibrilation (174).

There are studies showing that supraventricular rhythm disorders can lead to cardiorespiratory arrest in hemodialysis patients. SCD patients can suffer from bradycardia (26.3\%), asystole (15.8\%) and electromechanical dissociation (15.8\%) (175). There are few data regarding fatal supraventricular arrythmias, which do not respond to the classical ressuscitation measures, electrical defibrilation included. In order to obtain more knowledge in this respect, the Monitoring in Dialysis Study reports on the use of implantable loop recorders employed to analyze the type and frequency of arrythmias on the traces obtained in a 6-month period (176). The final results of the study have not been published yet, but the preliminary results for 66 enrolled patients show the presence of atrial arrythmias (57.4\%), bradycardia (15\%) and of ventricular arrythmia in only $9.1 \%$ of the cases, mainly in the postdialysis period (177).

\section{Management}

Primary prevention of SCD. Taking into consideration the frequency and the importance of this phenomenon, identifying the risk factors for SCD proves to be significant. SCD risk occurs in the first three months following the onset of hemodialysis and builds up directly proportional with the period of dialysis, which means both new and old patients can be considered at risk (164). In addition, at risk for SCD are hemodialysis patients who suffer from large IDWG, extreme variations in serum potassium (hypo/hyperpotassemia), uncorrected mineral or bone deficiencies or malnutrition $(89,178)$.

SCD hemodialysis patients are generally diabetics, with preexisting cardiac pathology and a history of cardiac arrythmias (179-181). There are studies that emphasize the strong association between SCD and inflammatory markers including interleukin (IL)-6 (181), C reactive protein (CRP) (182) and adiponectin (183), but also between SCD and nutrition markers: Serum albumin (182) and predialysis serum creatinine (89).

Medication. Several drugs have proven useful in lowering the risk of SCD. In this respect, $\beta$ adrenergic blockers were found to reduce SCD risk following myocardial infarction (184). A study of 200 hemodialysis patients assessed the efficiency of lisinopril vs. atenolol in reducing left ventricle hypertrophy and reported a significantly lower number of hospital admissions for cardiovascular events and cardiac failure in a group of patients who were treated with atenolol (185). Patients treated with atenolol had fewer episodes of arrythmia and cardiorespiratory arrest. On the other hand, the HEMO study did not show an association between $\beta$-blockers and the decrease in SCD risk (186). However, the initiation of treatment with $\beta$-blockers in hemodialysis patients to prevent SCD cannot be recommended, based on present data.

There is no clear evidence that treatment with cholesterol-lowering medication (statin therapy) or renin-angiotensin-aldosterone system blockers, which is beneficial in the general population in lowering cardiovascular risk, would prove equally beneficial in hemodialysis patients (164).

Adjusting the hemodialysis prescription. The parameters of dialysis can be adjusted so as to prevent SCD. Thus, a low potassium level in the dialysate $(<2 \mathrm{mEq} / \mathrm{l})$ in patients with predialysis serum potassium within a normal limit increases the risk of $\operatorname{SCD}(89,107,161)$. A study on 30 hemodialysis patients who received potassium modeling vs. a fixed potassium dialysate demonstrated a decrease in ventricular arrythmias, which suggests that the gradual elimination of potassium excess has a protective effect compared to its linear elimination, the latter one with aritmogenous effect. Unfortunately, potassium modeling is not widely available in hemodialysis centers (164).

The decrease in the $\mathrm{Ca}^{2+}$ level in the dialysate is associated with elongation of the QT interval and ventricular arrhytmias $(187,188)$. Research has shown that exposure to low-calcium dialysate $(<2.5 \mathrm{mEq} / \mathrm{l})$ is associated with an increase in the risk of SCD by $40 \%$ (189). On the other hand, other studies have shown that the use of high-calcium dialysate is correlated with an increase in mortality, by acceleration of the vascular calcification and by increasing the myocardium vulnerability to arrhythmias (190-192).

In addition to the role of calcium in the dialysate, further studies are necessary to explain the role of vitamin D analogues, of phosphate binders and of calcimetics in SCD. Furthermore, it is necessary to control the phosphate serum levels, taking into account that the relationship between hyperphosphatemy and mortality has been demonstrated, probably because of myocardial calcifications and hemodynamic changes in microcirculation (193).

In addition to the electrolytic exchanges in hemodialysis patients, the relationship between cardiovascular mortality and high rate of ultrafiltration has been demonstrated (194). An ultrafiltration rate over $10 \mathrm{ml} / \mathrm{kg} / \mathrm{h}$ is associated with increased mortality (195). It is necessary to train the patient to respect dietary recommandations (to limit salt and fluid intake), to increase the frequency and duration of the dialysis sessions and to maintain a small gradient between serum sodium and the sodium in the dialysate (196). The temperature in the dialysate influences blood pressure and coronary circulation, a decrease in the dialysate temperature causing a decrease in IDH and myocardial ischemic injury, and the risk of cardiovascular death (197).

\section{Conclusion}

Acute intradialytic cardiovascular complications are commonly encountered in clinical practice and influence the quality of life, such as morbidity and the mortality rate of dialysis patients. In order to have detailed knowledge concerning the risk factors and the pathogenic mechanisms and to ensure an optimal management of these complications, more studies must be conducted.

\section{Acknowledgements}

Not applicable. 


\section{Funding}

No funding was received.

\section{Availability of data and materials}

All information included in this review is documented by relevant references.

\section{Authors' contributions}

DT, MDT, DGB, AT, OS, IAV, AM, PCC, CIC, ME, DM, RIP and DI designed the review and wrote the manuscript and performed the literature search and selected the included studies. DT, MDT, DGB, AT, OS, IAV, AM, PCC, CIC, ME, DM, RIP and DI critically revised the manuscript. All authors read and approved the final manuscript. The contributions of all the authors toward this review are greatly valued and appreciated.

\section{Ethics approval and consent to participate}

Not applicable.

\section{Patient consent for publication}

Not applicable.

\section{Competing interests}

The authors declare that they have no competing interests.

\section{References}

1. Ozkan G and Ulusoy S: Acute Complications of Hemodialysis In: Technical Problems in Patients on Hemodialysis. Penido MG (ed). InTech, 2011. https://www.intechopen. com/books/technical-problems-in-patients-on-hemodialysis/acutecomplications-of-hemodialysis. Accessed December 7, 2011.

2. Balan DG, Stroescu AEB, Tanasescu MD, Diaconescu A, Raducu L, Mihai A, Tanase M, Stanescu II and Ionescu D: Nutritional intervention in patients with diabetic renal diseases. A brief presentation. Rev Chim 69: 3178-3182, 2018.

3. Balcangiu-Stroescu AE, Tanasescu MD, Diaconescu AC, Raducu L, Balan DG, Mihai A, Tanase M, Stanescu II and Ionescu D: Diabetic nephropathy: A concise assessment of the causes, risk factors and implications in diabetic patients. Rev Chim 69: 3118-3121, 2018.

4. Mandita A, Timofte D, Balcangiu-Stroescu AE, Balan DG, Raducu L, Tanasescu MD, Diaconescu AC, Dragos D Cosconel CI, Stoicescu SM, et al: Treatment of high blood pressure in patients with chronic renal disease. Rev Chim 70: 993-995, 2019

5. National Institute of Diabetes and Digestive and Kidney Diseases (NIDDK): Kidney Disease Statistics for the United States. https://www.niddk.nih.gov/health-information/health-statistics/ kidney-disease. Accessed November 2, 2019.

6. Saha M and Allon M: Diagnosis, treatment, and prevention of hemodialysis emergencies. Clin J Am Soc Nephrol 12: 357-369, 2017.

7. United States Renal Data System (USRDS): 2009 Annual Report United States Renal Data System. https://www.usrds.org/.

8. Bregman H, Daugirdas JT and Ing TS: Complications during hemodialysis. In: Handbook of Dialysis. Dauugirdas JT and Ing TS (eds). Little, Brown, New York, NY, p149, 1994.

9. Paparello J, Kshirsagar A and Batlle D: Comorbidity and cardiovascular risk factors in patients with chronic kidney disease. Semin Nephrol 22: 494-506, 2002.
10. Olariu L, Dumitriu B, Craciun L, Buse E, Rosoiu N, Bojinca M and Papacocea T: The in vitro influence of a pharmaceutically active small sea fish extract on apoptosis and proliferation mechanisms amplified by inflammatory conditions. Farmacia 67: 140-145, 2019.

11. Balcangiu-Stroescu AE, Tanasescu MD, Diaconescu AC, Raducu L, Constantin AM, Balan DG, Tharmure V and Ionescu D: Cardiovascular comorbidities, inflammation and serum albumin levels in a group of hemodialysis patients. Rev Chim Buchar 69: 926-929, 2018.

12. Timofte D, Mandita A, Balcangiu-Stroescu AE, Balan DG, Raducu L, Tanasescu MD, Diaconescu AC, Dragos D, Cosconel CI, Stoicescu SM, et al: Hyperuricemia and cardiovascular diseases-clinical and paraclinical correlations. Rev Chim Buchar 70: 1045-1046, 2019.

13. Totan A, Balcangiu-Stroescu AE, Melescanu Imre M, Miricescu D, Balan DG, Stanescu II, Ionescu D, Timofte D, Tanasescu MD and Greabu M: XOR-Possible correlations with oxidative stress and inflammation markers in the context of diabetic kidney disease. Rev Chim Buchar 70: 1396-1398, 2019.

14. Sars B, van der Sande FM and Kooman PJ: Intradialytic Hypotension: Mechanisms and outcome. Blood Purif 49: 158-167, 2020.

15. Flythe JE, Xue H, Lynch KE, Curhan GC and Brunelli SM: Association of mortality risk with various definitions of intradialytic hypotension. J Am Soc Nephrol 26: 724-734, 2015.

16. Sands JJ, Usvyat LA, Sullivan T, Segal JH, Zabetakis $P$, Kotanko P, Maddux FW and Diaz-Buxo JA: Intradialytic hypotension: Frequency, sources of variation and correlation with clinical outcome. Hemodial Int 18: 415-422, 2014.

17. Reilly RF: Attending rounds: A patient with intradialytic hypotension. Clin J Am Soc Nephrol 9: 798-803, 2014.

18. Assimon MM and Flythe JE: Definitions of intradialytic hypotension. Semin Dial 30: 464-472, 2017.

19. Masani NN, Miyawaki N and Maesaka JK: A patient with an uncommon etiology of intradialytic hypotension. Semin Dial 18: 435-439, 2005.

20. Roy PN and Danziger RS: Dialysate magnesium concentration predicts the occurrence of intradialytic hypotension. J Am Soc Nephrol 7: 1496, 1996.

21. Van der Sande FM, Cheriex EC, van Kuijk WH and Leunissen KM: Effect of dialysate calcium concentrations on intradialytic blood pressure course in cardiac-compromised patients. Am J Kidney Dis 32: 125-131, 1998.

22. Alappan R, Cruz D, Abu-Alfa AK, Mahnensmith R and Perazella MA: Treatment of severe intradialytic hypotension with the addition of high dialysate calcium concentration to midodrine and/or cool dialysate. Am J Kidney Dis 37: 294-299, 2001.

23. Lin CJ, Chen CY, Wu PC, Pan CF, Shih HM, Huang MY, Chou LH, Tang JS and Wu CJ: Intelligent system to predict intradialy tic hypotension in chronic hemodialysis. J Formos Med Assoc 117: 888-893, 2018

24. Seabra VF and Jaber BL: Acute complications during hemodialysis. In: Comprehensive Clinical Nephrology. Floege J, Johnson RJ and Feehally J (eds). Elsevier, Philadelphia, PA, pp1306-1307, 2010.

25. Kooman JP, Katzarski K, van der Sande FM, Leunissen KM and Kotanko P: Hemodialysis: A model for extreme physiology in a vulnerable patient population. Semin Dial 31: 500-506, 2018.

26. Barth C, Boer W, Garzoni D, Kuenzi T, Ries W, Schaefer R, Schneditz D, Tsobanelis T, van der Sande F, Wojke R, et al: Characteristics of hypotension-prone haemodialysis patients: Is there a critical relative blood volume? Nephrol Dial Transplant 18: 1353-1360, 2003.

27. Aronoff GR: The effect of treatment time, dialysis frequency, and ultrafiltration rate on intradialytic hypotension. Semin Dial 30: 489-491, 2017.

28. Levin NW, de Abreu MHFG, Borges LE, Tavares HA, Sarwar R, Gupta S, Hafeez T, Lev S and Williams C: Hemodynamic response to fluid removal during hemodialysis: Categorization of causes of intradialytic hypotension. Nephrol Dial Transplant 33: 1643-1649, 2018

29. Feng Y, Zou Y, Zheng Y, Levin NW and Wang L: The value of non-invasive measurement of cardiac output and total peripheral resistance to categorize significant changes of intradialytic blood pressure: A prospective study. BMC Nephrol 19: 310, 2018.

30. van der Sande FM, Dekker MJ, Leunissen KM and Kooman JP: Novel insights into the pathogenesis and prevention of intradialytic hypotension. Blood Purif 45: 230-235, 2018. 
31. Assa S, Hummel YM, Voors AA, Kuipers J, Westerhuis R, de Jong PE and Franssen CFM: Hemodialysis-induced regional left ventricular systolic dysfunction: Prevalence, patient and dialysis treatment-related factors, and prognostic significance. Clin J Am Soc Nephrol 7: 1615-1623, 2012.

32. Seong EY, Zheng Y, Winkelmayer WC, Montez-Rath ME and Chang TI: The relationship between intradialytic hypotension and hospitalized mesenteric ischemia: A case-control study. Clin J Am Soc Nephrol 13: 1517-1525, 2018.

33. Magder SA: The highs and lows of blood pressure: Toward meaningful clinical targets in patients with shock. Crit Care Med 42: 1241-1251, 2014

34. Charytan DM, Skali H, Shah NR, Veeranna V, Cheezum MK, Taqueti VR, Kato T, Bibbo CR, Hainer J, Dorbala S, et al: Coronary flow reserve is predictive of the risk of cardiovascular death regardless of chronic kidney disease stage. Kidney Int 93 : 501-509, 2018

35. Burkhardt D, Bartosova M, Schaefer B, Grabe N, Lahrmann B Nasser H, Freise C, Schneider A, Lingnau A, Degenhardt P, et al: Reduced microvascular density in omental biopsies of children with chronic kidney disease. PLoS One 11: e0166050, 2016.

36. Mitsides N, Cornelis T, Broers NJ, Diederen NM, Brenchley P, van der Sande FM, Schalkwijk CG, Kooman JP and Mitra S: Extracellular overhydration linked with endothelial dysfunction in the context of inflammation in haemodialysis dependent chronic kidney disease. PLoS One 12: e0183281, 2017.

37. Amann K, Wiest G, Zimmer G, Gretz N, Ritz E and Mall G: Reduced capillary density in the myocardium of uremic rats-a stereological study. Kidney Int 42: 1079-1085, 1992.

38. Mancini E, Perazzini C, Gesualdo L, Aucella F, Limido A Scolari F, Savoldi S, Tramonti M, Corazza L, Atti M, et al: Intra-dialytic blood oxygen saturation $\left(\mathrm{SO}_{2}\right)$ : Association with dialysis hypotension (the SOGLIA Study). J Nephrol 30: 811-819, 2016.

39. Campos I, Chan L, Zhang H, Deziel S, Vaughn C, Meyring-Wösten A and Kotanko P: Intradialytic hypoxemia in chronic hemodialysis patients. Blood Purif 41: 177-187, 2016.

40. Knoll GA, Grabowski JA, Dervin GF and O'Rourke K: A randomized, controlled trial of albumin versus saline for the treatment of intradialytic hypotension. J Am Soc Nephrol 15: 487-492, 2004.

41. Nette RW, Krepel HP, van den Meiracker AH, Weimar W and Zietse R: Specific effect of the infusion of glucose on blood volume during haemodialysis. Nephrol Dial Transplant 17: 1275-1280, 2002.

42. Kouw PM, Kooman JP, Cheriex EC, Olthof CG, de Vries PM and Leunissen KM: Assessment of postdialysis dry weight: A comparison of techniques. J Am Soc Nephrol 4: 98-104, 1993.

43. Donauer J, Kölblin D, Bek M, Krause A and Bohler J: Ultrafiltration profiling and measurement of relative blood volume as strategies to reduce hemodialysis-related side effects. Am J Kidney Dis 36: 115-123, 2000.

44. Déziel C, Bouchard J, Zellweger M and Madore F: Impact of hemocontrol on hypertension, nursing interventions, and quality of life: A randomized, controlled trial. Clin J Am Soc Nephrol 2: 661-668, 2007

45. Basile C, Vernaglione L, Di Iorio B, Bellizzi V, Chimienti D, Lomonte C, Rubino A and D'Ambrosio N: Development and validation of bioimpedance analysis prediction equations for dry weight in hemodialysis patients. Clin J Am Soc Nephrol 2: 675-680, 2007.

46. Palmer BF and Henrich WL: Recent advances in the prevention and management of intradialytic hypotension. J Am Soc Nephrol 19: 8-11, 2008

47. Caetano C, Valente A, Oliveira T and Garagarza C: Coffee consumption in hemodialysis patients: How many? Eur J Clin Nutr 73: 924-929, 2018

48. Papacocea R, Badarau IA, Ciornei CM, Burciulescu Lider S and Papacocea MT: The effects of caffeine intake on cardiovascular in sleep deprived medical residents. Rev Chim Buchar 70: $1445-1448,2019$.

49. Kearney MT, Cowley AJ, Stubbs TA, Evans A and Macdonald IA Depressor action of insulin on skeletal muscle vasculature: A novel mechanism for postprandial hypotension in the elderly. J Am Coll Cardiol 31: 209-216, 1998.

50. Kutlugün AA, Erdem Y, Okutucu S, Yorgun H Atalar E and Arici M: Effects of lowering dialysate sodium on flow-mediated dilatation in patients with chronic kidney disease. Nephrol Dial Transplant 26: 3678-3682, 2011.

51. Mc Causland FR, Brunelli SM and Waikar SS: Dialysate sodium, serum sodium and mortality in maintenance hemodialysis. Nephrol Dial Transplant 27: 1613-1618, 2012.
52. Basile C, Pisano A, Lisi P, Rossi L, Lomonte C and Bolignano D: High versus low dialysate sodium concentration in chronic haemodialysis patients: A systematic review of 23 studies. Nephrol Dial Transplant 31: 548-563, 2016.

53. Marshall MR, Vandal AC, de Zoysa JR, Gabriel RS, Haloob IA, Hood JC, Irvine JH, Matheson PJ, McGregor DOR, Rabindranath KS, et al: Effect of low-sodium versus conventional sodium dialysate on left ventricular mass in home and self-care satellite facility hemodialysis patients: A randomized clinical trial. J Am Soc Nephrol 31: 1078-1091, 2020.

54. Jindal K, Chan CT, Deziel C, Hirsch D, Soroka SD, Tonelli M and Culleton BF; Canadian Society of Nephrology Committee for Clinical Practice Guidelines: Hemodialysis clinical practice guidelines for the Canadian Society of Nephrology. J Am Soc Nephrol 17 (3 Suppl 1): S1-S27, 2006.

55. Maggiore Q, Pizzarelli F, Zoccali C, Sisca S, Nicolo F and Parlongo S: Effect of extracorporeal blood cooling on dialytic arterial hypotension. Proc Eur Dial Transplant Assoc 18: 597-602, 1981

56. Lindholm T, Thysell H, Yamamoto Y, Forsberg B and Gullberg CA: Temperature and vascular stability in hemodialysis. Nephron 39: 130-133, 1985.

57. Sherman RA, Rubin MP, Cody RP and Eisinger RP: Amelioration of hemodialysis-associated hypotension by the use of cool dialysate. Am J Kidney Dis 5: 124-127, 1985.

58. Quereda C, Orofino L, Marcen R, Sabater J, Matesanz R and Ortuno J: Influence of dialysate and membrane biocompatibility on hemodynamic stability in hemodialysis. Int J Artif Organs 11: 259-264, 1988

59. Orofino L, Marcén R, Quereda C, Villafruela JJ, Sabater J, Matesanz R, Pascual J and Ortuno J: Epidemiology of symptomatic hypotension in hemodialysis: Is cool dialysate beneficial for all patients? Am J Nephrol 10: 177-180, 1990.

60. Jost CM, Agarwal R, Khair-el-Din T, Grayburn PA, Victor RG and Henrich WL: Effects of cooler temperature dialysate on hemodynamic stability in 'problem' dialysis patients. Kidney Int 44: 606-612, 1993

61. Schneditz D, Martin K, Krämer M, Kenner T and Skrabal F: Effect of controlled extracorporeal blood cooling on ultrafiltration-induced blood volume changes during hemodialysis. J Am Soc Nephrol 8: 956-964, 1997.

62. Cruz DN, Mahnensmith RL, Brickel HM and Perazella MA Midodrine and cool dialysate are effective therapies for symptomatic intradialytic hypotension. Am J Kidney Dis 33: 920-926, 1999.

63. Yu AW, Ing TS, Zabaneh RI and Daugirdas JT: Effect of dialysate temperature on central hemodynamics and urea kinetics. Kidney Int 48: 237-243, 1995.

64. Schneditz D, Ronco C and Levin N: Temperature control by the blood temperature monitor. Semin Dial 16: 477-482, 2003.

65. Pérgola PE, Habiba NM and Johnson JM: Body temperature regulation during hemodialysis in long-term patients: Is it time to change dialysate temperature prescription? Am J Kidney Dis 44: $155-165,2004$.

66. Pizzarelli F: From cold dialysis to isothermic dialysis: A twenty-five year voyage. Nephrol Dial Transplant 22: 1007-1012, 2007.

67. Mustafa RA, Bdair F, Akl EA, Garg AX, Thiessen-Philbrook H, Salameh H, Kisra S, Gihad N, Al-Jaishi A, Patel P, et al: Effect of lowering the dialysate temperature in chronic hemodialysis: A Systematic review and meta-analysis. Clin J Am Soc Nephrol 11: 442-457, 2016

68. Flynn JJ III, Mitchell MC, Caruso FS and McElligott MA: Midodrine treatment for patients with hemodialysis hypotension. Clin Nephrol 45: 261-267, 1996.

69. Montagnac R, Clavel P, Delhotal-Landes B, Flouvat B, Poulain S and Schllinger F: Use of midodrine (Gutron) to treat permanen hypotension in a chronic hemodialysis patient. Clin Nephrol 56: 162-168, 2001.

70. Perazella MA: Pharmacologic options available to treat symptomatic intradialytic hypotension. Am J Kidney Dis 38 (4 Suppl 4): $S 26-S 36,2001$

71. Prakash S, Garg AX, Heidenheim AP and House AA: Midodrine appears to be safe and effective for dialysis-induced hypotension: A systematic review. Nephrol Dial Transplant 19: 2553-2558, 2004.

72. Low PA, Gilden JL, Freeman R, Sheng KN and McElligott MA: Efficacy of midodrine vs. placebo in neurogenic orthostatic hypotension. A randomized, double-blind multicenter study. Midodrine Study Group. JAMA 277: 1046-1051, 1997.

73. Dheenan S, Venkatesan J, Grubb BP and Henrich WL: Effect of sertraline hydrochloride on dialysis hypotension. Am J Kidney Dis 31: 624-630, 1998 . 
74. Imai E, Fujii M, Kohno Y, Kageyama H, Nakahara K, Hori M and Tsubakihara Y: Adenosine A1 receptor antagonist improves intradialytic hypotension. Kidney Int 69: 877-883, 2006.

75. Tattersall J, Martin-Malo A, Pedrini L, Basci A, Canaud B, Fouque D, Haage P, Kinner K, Kooman J, Pizzarelli F, et al: EBPG guideline on dialysis strategies. Nephrol Dial Transplant 22 (Suppl 2): ii5-ii21, 2007.

76. Merino JL, Rivera M, Teruel JL, Mercén R and Ortuño J: CAPD as treatment of chronic debilitating hemodialysis hypotension. Perit Dial Int 22: 429, 2002.

77. Van Buren PN, Kim C, Toto RD and Inrig JK: The prevalence of persistent intradialytic hypertension in a hemodialysis population with extended follow-up. Int J Artif Organs 35: 1031-1038, 2012.

78. Chou KJ, Lee PT, Chen CL, Chiou CW, Hsu CY, Chung HM, Liu CP and Fang HC: Physiological changes during hemodialysis in patients with intradialysis hypertension. Kidney Int 69: 1833-1838, 2006.

79. Inrig JK, Van Buren P, Kim C, Vongpatanasin W, Povsic TJ and Toto RD: Intradialytic hypertension and its association with endothelial cell dysfunction. Clin J Am Soc Nephrol 6 : 2016-2024, 2011

80. Van Buren PN: Pathophysiology and implications of intradialytic hypertension. Curr Opin Nephrol Hypertens 26: 303-310, 2017.

81. Park J, Rhee C, Sim J, Kim YL, Ricks J, Streja E, Vashistha T, Tolouian R, Kovesdy CP and Zadeh K: A comparative effectiveness research study of the change in blood pressure during hemodialysis treatment and survival. Kidney Int 84: 795-802, 2013.

82. Agarwal R and Light RP: Intradialytic hypertension is a marker of volume excess. Nephrol Dial Transplant 25: 3355-3361, 2010.

83. Van Buren PN, Kim C, Toto R and Inrig JK: Intradialytic hypertension and the association with interdialytic ambulatory blood pressure. Clin J Am Soc Nephrol 6: 1684-1691, 2011.

84. Agarwal R, Alborzi P, Satyan S and Light RP: Dry-weight reduction in hypertensive hemodialysis patients (DRIP): A randomized, controlled trial. Hypertension 53: 500-507, 2009.

85. McCausland F and Waikar S: Association of predialysis calculated plasma osmolarity with intradialytic blood pressure decline. Am J Kidney Dis 66: 499-506, 2015

86. Movilli E, Camerini C, Gaggia P, Zubani R, Feller P, Poiatti P, Pola A, Carli O, Valzorio B and Cancarini G: Role of dialysis sodium gradient on intradialytic hypertension: An observational study. Am J Nephrol 38: 413-419, 2013

87. Dolson GM, Ellis KJ, Bernardo MV, Prakash R and Adrogué HJ: Acute decreases in serum potassium augment blood pressure. Am J Kidney Dis 26: 321-326, 1995.

88. Gabutti L, Bianchi G, Soldini D, Marone C and Burnier M Haemodynamic consequences of changing bicarbonate and calcium concentrations in haemodialysis fluids. Nephrol Dial Transplant 24: 973-981, 2009.

89. Pun PH,Lehrich RW, Honeycutt EF, Herzog CA and Middleton JP Modifiable risk factors associated with sudden cardiac arrest within hemodialysis clinics. Kidney Int 79: 218-227, 2011.

90. Fellner SK, Lang RM, Neumann A, Spencer KT, Bushinsky DA and Borow KM: Physiological mechanisms for calcium-induced changes in systemic arterial pressure in stable dialysis patients. Hypertension 13: 213-218, 1989.

91. LeBeouf A, Mac-Way F, Utescu MS, Chbinou N, Douville P, Desmeules S and Agharazii M: Effects of acute variation of dialysate calcium concentrations on arterial stiffness and aortic pressure waveform. Nephrol Dial Transplant 24: 3788-3794, 2009.

92. Van Buren PN, Zhou Y, Neyra JA, Xiao G, Vongpatanasin W, Inrig $\mathrm{J}$ and Toto R: Extracellular volume overload and increased vasoconstriction in patients with recurrent intradialytic hypertension. Kidney Blood Press Res 41: 802-814, 2016.

93. Raj DSC, Vincent B, Simpson K, Sato E, Jones KL, Welbourne TC, Levi M, Shah V, Blandon P, Zager P and Robbins RA: Hemodynamic changes during hemodialysis: Role of nitric oxide and endothelin. Kidney Int 61: 697-704, 2002.

94. El-Shafey EM, El-Nagar GF, Selim MF, El-Sorogy HA and Sabry AA: Is there a role for endothelin-1 in the hemodynamic changes during hemodialysis? Clin Exp Nephrol 12: 370-375, 2008 .
95. Gutierrez-Adrianzen OA, Moraes ME, Almeida AP, Lima JW, Marinho MF, Marques AL, Madeiro JP, Nepomuceno L, da Silva JM Jr, Silva GB Jr, et al: Pathophysiological, cardiovascular and neuroendocrine changes in hypertensive patients during the hemodialysis session. J Hum Hypertens 29: 366-372, 2015.

96. Teng J, Tian J, Lv WL, Zhang XY, Zou JZ, Fang Y, Yu J, Shen B, Liu ZH and Ding XQ: Inappropriately elevated endothelin-1 plays a role in the pathogenesis of intradialytic hypertension. Hemodial Int 19: 279-286, 2015.

97. Sinha AD, Light RP and Agarwal R: Relative plasma volume monitoring during hemodialysis AIDS the assessment of dry weight. Hypertension 55: 305-311, 2010.

98. Inrig J, Van Buren P, Kim C, Vongpatanasin W, Povsic TJ and Toto R: Probing the mechanisms of intradialytic hypertension: A pilot study targeting endothelial cell dysfunction. Clin J Am Soc Nephrol 7: 1300-1309, 2012.

99. Inrig JK, Molina C, D'Silva K, Kim C, Van Buren P, Allen J and Toto R: Effect of low versus high dialysate sodium concentration on blood pressure and endothelial-derived vasoregulators during hemodialysis: A randomized crossover study. Am J Kidney Dis 65: 464-473, 2015.

100. Voroneanu L and Covic A: Arrhythmias in hemodialysis patients. J Nephrol 22: 716-725, 2009.

101. United States Renal Data System (USRDS): USRDS 2013 Annual Data Report: Atlas of End-Stage Renal Disease in the United States. National Institutes of Health, National Institute of Diabetes and Digestive and Kidney Diseases, Bethesda, MD, 2013. https://www.usrds.org/atlas13.aspx Accessed June 25, 2020.

102. Zebe H: Atrial fibrillation in dialysis patients. Nephrol Dial Transplant 15: 765-768, 2000

103. Vazquez E, Sanchez-Perales C, Borrego F, Garcia-Cortes MJ, Lozano C, Guzman M, Gil JM, Borrego MJ and Perez V: Influence of atrial fibrillation on the morbido-mortality of patients on hemodialysis. Am Heart J 140: 886-890, 2000.

104. Genovesi S, Vincenti A, Rossi E, Pogliani D, Acquistapace I, Stella A and Valsecchi MG: Atrial fibrillation and morbidity and mortality in a cohort of long-term hemodialysis patients. Am J Kidney Dis 51: 255-262, 2008.

105. Abbott KC, Trespalacios FC, Taylor AJ and Agodoa LY: Atrial fibrillation in chronic dialysis patients in the United States: Risk factors for hospitalization and mortality. BMC Nephrol 4: 1, 2003.

106. Hecking E, Bragg-Gresham JL, Rayner HC, Pisoni RL, Andreuci VE, Combe C, Greenwood R, McCullough, Feldman HI, Young EW, et al: Haemodialysis prescription, adherence and nutritional indicators in five European countries: Results from the dialysis Outcomes and practice patterns Study (DOPPS). Nephrol Dial Transplant 19: 100-107, 2004.

107. Karnik JA, Young BS, Lew NL, Herget M, Dubinsky C, Lazarus JM and Chertow GM: Cardiac arrest and sudden death in dialysis units. Kidney Int 60: 350-357, 2001.

108. Genovessi S, Pogliani D, Faini A, Valsecchi MG, Riva A, Stefani F, Acquistapace I, Stella A, Bonforte G, DeVecchi A, et al: Prevalence of atrial fibrillation and associated factors in a population of long-term hemodialysis patients. Am J Kidney Dis 46: 897-902, 2005.

109. Fischer R, Dechend R, Gapelyuk A, Shagdarsuren E, Gruner K, Gratze A, Gratze P, Qadri F, Wellner M, Fiebeler A, et al: Angiotensin II-induced sudden arrhythmic death and electrical remodeling. Am J Physiol Heart Circ Physiol 293: H1242-H1253, 2007.

110. Fierbinteanu-Braticevici C, Papacocea R, Tribus L and Băicuş C: Role of ${ }^{13} \mathrm{C}$ Methacetin breath test for noninvasive staging of liver fibrosis in patients with chronic hepatitis C. Indian J Med Res 140: 123-129, 2014.

111. Takeda K, Nakamoto M, Baba M, Tanaka T, Yasunaga C, Nishihara G, Matsuo K and Urabe M: Echocardiographic evaluation in long-term continuous ambulatory peritoneal dialysis compared with the hemodialysis patients. Clin Nephrol 49: 308-312, 1998.

112. Tica OA, Tica O, Antal L, Hatos A, Popescu MI, Pantea Stoian A, Bratu OG, Găman MA, Pituru SM and Diaconu CC: Modern oral anticoagulant treatment in patients with atrial fibrillation and heart failure: Insights from the clinical practice. Farmacia 66: 972-976, 2018

113. Laslo C, Pantea Stoian A, Socea B, Paduraru D, Bodean O, Socea L, Neagu TP, Stanescu AMA, Marcu D and Diaconu CC: New oral anticoagulants and their reversal agents. J Mind Med Sci 5: 195-201, 2018 
114. Routledge HC, Chowdhary S and Townend JN: Heart rate variability: A therapeutic target? J Clin Pharm Ther 27: 85-92, 2002.

115. Herzog CA: Don't forget the defibrillator in the dialysis unit Nephrol Dial Transplant 19: 2959-2960, 2004.

116. Sakhuja R, Keebler M, Lai TS, McLaughli Gavin C, Thakur R and Bhatt DL: Meta-analysis of mortality in dialysis patients with an implantable cardioverter defibrillator. Am J Cardiol 103: 735-741, 2009.

117. Anavekar NS, McMurray JJ, Velazquez EJ, Solomon SD, Kober L, Rouleau JL, White HD, Nordlander R, Maggioni A, Dickstein K, et al: Relation between renal dysfunction and cardiovascular outcomes after myocardial infarction. N Engl J Med 351: 1285-1295, 2004.

118. Go AS, Chertow GM, Fan D, McCulloch CE and Hsu C: Chronic kidney disease and the risks of death, cardiovascular events, and hospitalization. N Engl J Med 351: 1296-1305, 2004

119. Collins AJ, Foley RN, Herzog C, Chavers B, Gilbertson D, Ishani A, Kasiske B, Liu J, Mau LW, McBean M, et al: United States renal data system 2008 annual data report abstract. Am J Kidney Dis 53 (1 Suppl): S1-S374, 2009.

120. Ix JH, Shlipak MG, Liu HH, Schiller NB and Whooley MA Association between renal insufficiency and inducible ischemia in patients with coronary artery disease: The heart and soul study. J Am Soc Nephrol 14: 3233-3238, 2003.

121. Sarnak MJ, Levey AS, Schoolwerth AC, Coresh J, Culleton B, Hamm LL, McCullough PA, Kasiske BL, Kelepouris E, Klag MJ, et al: Kidney disease as a risk factor for development of cardiovascular disease: A statement from the American Heart Association Councils on Kidney in Cardiovascular Disease, High Blood Pressure Research, Clinical Cardiology, and Epidemiology and Prevention. Circulation 108: 2154-2169, 2003.

122. Go AS, Bansal N, Chandra M, Lathon PV, Fortmann SP, Iribarren C, Hsu CY and Hlatky M; ADVANCE Study Investigators: Chronic kidney disease and risk for presenting with acute myocardial infarction versus stable exertional angina in adults with coronary heart disease. J Am Coll Cardiol 58: 1600-1607, 2011

123. Collins AJ, Foley RN, Herzog C, Chavers BM, Gilbertson D, Ishani A, Kasiske BL, Liu J, Mau LW, McBean M, et al: Excerpts from the US renal data system 2009 annual data report. Am J Kidney Dis 55 (1 Suppl 1): S1-S420, A6-A7, 2010.

124. United States Renal Data System (USRDS): USRDS 2013 annual data report: atlas of chronic kidney disease and endstage renal disease in the United States. National Institutes of Health, National Institute of Diabetes and Digestive and Kidney Diseases, Bethesda, MD, 2013. https://www.usrds.org/atlas13. aspx. Accessed August 19, 2016.

125. Herzog CA and Passman R: Evaluation of sudden cardiac arrest and sudden cardiac death in dialysis patients. UpToDate, 2020. https://www.uptodate.com/contents/evaluation-of-sudden-cardiacarrest-and-sudden-cardiac-death-in-dialysis-patients. Accessed June 2, 2020.

126. Muntner P, He J, Hamm L, Loria C and Whelton PK: Renal insufficiency and subsequent death resulting from cardiovascular disease in the United States. J Am Soc Nephrol 13: 745-753, 2002.

127. Di Benedetto A, Marcelli D, D'Andrea A, Cice G, D'Isa S, Cappabianca F, Pacchiano G, D'Amato R, Oggero AR, Bonanno D, et al: Risk factors and underlying cardiovascular diseases in incident ESRD patients. J Nephrol 18: 592-598, 2005.

128. Shah DS, Polkinghorne KR, Pellicano R and Kerr PG: Are traditional risk factors valid for assessing cardiovascular risk in end-stage renal failure patients? Nephrology (Carlton) 13: 667-671, 2008.

129. Levey AS, Coresh J, Balk E, Kausz AT, Levin A, Steffes MW, Hogg RJ, Perrone RD, Lau J and Eknoyan G; National Kidney Foundation: National kidney foundation practice guidelines for chronic kidney disease: Evaluation, classification, and stratification. Ann Intern Med 139: 137-147, 2003.

130. Antman EM, Anbe DT, Armstrong PW, Bates ER, Green LA, Hand M, Hochman JS, Krumhols H, Kushner FG, Lamas GA, et al: ACC/AHA guidelines for the management of patients with ST-elevation myocardial infarction-executive summary: A report of the American College of Cardiology/American Heart Association Task Force on Practice Guidelines (Writing Committee to Revise the 1999 Guidelines for the Management of Patients With Acute Myocardial Infarction). Circulation 110: 588-636, 2004.
131. Van der Velde M, Matsushita K, Coresh J, Astor BC, Woodward M, Levey A, de Jong P, Gansevoort RT; Chronic Kidney Disease Prognosis Consortium, van der Velde M, et al: Lower estimated glomerular filtration rate and higher albuminuria are associated with all-cause and cardiovascular mortality. A collaborative meta-analysis of high-risk population cohorts. Kidney Int 79: 1341-1352, 2011.

132. Hörl WH, Cohen JJ, Harrington JT, Madias NE and Zusman CJ: Atherosclerosis and uremic retention solutes. Kidney Int 66: 1719-1731, 2004.

133. Becker BN, Himmelfarb J, Henrich WL and Hakim RM: Reassessing the cardiac risk profile in chronic hemodialysis patients: A hypothesis on the role of oxidant stress and other non-traditional cardiac risk factors. J Am Soc Nephrol 8: 475-486, 1997.

134. Harper SJ and Bates DO: Endothelial permeability in uremia. Kidney Int Suppl 63: S84-S44, 2003.

135. Stenvinkel P, Pecoits-Filho R and Lindholm B: Coronary artery disease in end-stage renal disease: No longer a simple plumbing problem. J Am Soc Nephrol 14: 1927-1939, 2003.

136. Buzello M, Törnig J, Faulhaber J, Ehmke H, Ritz E and Amann K: The apolipoprotein e knockout mouse: A model documenting accelerated atherogenesis in uremia. J Am Soc Nephrol 14: 311-316, 2003.

137. Bro S, Bentzon JF, Falk E, Andersen CB, Olgaard K and Nielsen LB: Chronic renal failure accelerates atherogenesis in apolipoprotein E-deficient mice. J Am Soc Nephrol 14: 2466-2474, 2003.

138. Bro S, Moeller F, Andersen CB, Olgaard K and Nielsen LB: Increased expression of adhesion molecules in uremic atherosclerosis in apolipoprotein-E-deficient mice. J Am Soc Nephrol 15: 1495-1503, 2004.

139. Deicher R, Ziai F, Bieglmayer C, Schillinger M and Horl WH: Low total vitamin $\mathrm{C}$ plasma level is a risk factor for cardiovascular morbidity and mortality in hemodialysis patients. J Am Soc Nephrol 16: 1811-1818, 2005.

140. Antoniades C, Demosthenous M, Tousoulis D, Antonopoulos AS Vlachopoulos C, Toutouza M, Marinou K, Bakogiannis C, Mavragani K, Lazaros G, et al: Role of asymmetrical dimethylarginine in inflammation-induced endothelial dysfunction in human atherosclerosis. Hypertension 58: 93-98, 2011.

141. Juonala M, Viikari JS, Alfthan G, Marniemi J, Kahonen M, Taittonen L, Laitinen T and Raitakari OT: Brachial artery flow-mediated dilation and asymmetrical dimethylarginine in the cardiovascular risk in young Finns study. Circulation 116: 1367-1373, 2007.

142. Zoccali C, Bode-Böger S, Mallamaci F, Benedetto F, Tripepi G, Malatino L, Cataliotti A, Bellanuova I, Fermo I, Frolich J and Böger R: Plasma concentration of asymmetrical dimethylarginine and mortality in patients with end-stage renal disease: A prospective study. Lancet 358: 2113-2117, 2001.

143. Nuhu F and Bhandari S: Oxidative stress and cardiovascular complications in chronic kidney disease, the impact of anaemia. Pharmaceuticals (Basel) 11: 103, 2018.

144. Papacocea T, Buraga I, Papacocea R, Badarau AI, Buraga M, Ciornei C Mihai G, Stoian I and Adam D: Antioxidant enzymes-potential targets in intracerebral haemorrhage. Farmacia 62: 1118-1125, 2014

145. Vervloet M and Cozzolino M: Vascular calcification in chronic kidney disease: Different bricks in the wall? Kidney Int 91: 808-817, 2017.

146. Jablonski KL and Chonchol M: Vascular calcification in end-stage renal disease. Hemodial Int 17 (Suppl 1): S17-S21, 2013.

147. Sosnov J, Lessard D, Goldberg RJ, Yarzebski J and Gore JM: Differential symptoms of acute myocardial infarction in patients with kidney disease: A community-wide perspective. Am J Kidney Dis 47: 378-384, 2006.

148. Herzog CA, Littrell K, Arko C, Frederick PD and Blaney M: Clinical characteristics of dialysis patients with acute myocardial infarction in the United States: A collaborative project of the United States Renal Data System and the National Registry of Myocardial Infarction. Circulation 116: 1465-1472, 2007.

149. Freda BJ, Tang WH, Van Lente F, Peacock WF and Francis GS: Cardiac troponins in renal insufficiency: Review and clinical implications. J Am Coll Cardiol 40: 2065-2071, 2002.

150. Bonello L, De Labriolle A, Roy P, Steinberg DH, Okabe T, Pinto Slottow TL, Xue Z, Torguson R, Suddath WO, Satler LF, et al: Impact of optimal medical therapy and revascularization on outcome of patients with chronic kidney disease and on dialysis who presented with acute coronary syndrome. Am J Cardiol 102: 535-540, 2008. 
151. Keltai M, Tonelli M, Mann JF, Sitkei E, Lewis BS, Hawken S, Mehta SR and Yusuf S; CURE Trial Investigators: Renal function and outcomes in acute coronary syndrome: Impact of clopidogrel. Eur J Cardiovasc Prev Rehabil 14: 312-318, 2007.

152. Palmer SC, Di Micco L, Razavian M, Craig JC, Perkovic V, Pellegrini F, Copetti M, Graziano G, Tognoni G, Jardine M, et al: Effects of antiplatelet therapy on mortality and cardiovascular and bleeding outcomes in persons with chronic kidney disease: A systematic review and meta-analysis. Ann Intern Med 156: 445-459, 2012.

153. James S, Budaj A, Aylward P, Buck KK, Cannon CP, Cornel JH, Harrington RA, Horrow J, Katus H, Keltai M, et al: Ticagrelor versus clopidogrel in acute coronary syndromes in relation to renal function: Results from the Platelet Inhibition and Patien Outcomes (PLATO) trial. Circulation 122: 1056-1067, 2010.

154. Huang CC and Chen JW: Contemporary management of coronary artery disease and acute coronary syndrome in patients with chronic kidney disease and end-stage renal disease. Acta Cardiol Sin 29: 132-141, 2013.

155. Strippoli GF, Navaneethan SD, Johnson DW, Perkovic V, Pellegrini F, Nicolucci A and Craig JC: Effects of statins in patients with chronic kidney disease: Meta-analysis and metaregression of randomised controlled trials. BMJ 336: 645-651, 2008.

156. Chou MT, Wang JJ, Sun YM, Sheu MJ, Chu CC, Weng SF, Chio CC, Kan WC and Chien CC: Epidemiology and mortality among dialysis patients with acute coronary syndrome: Taiwan National Cohort Study. Int J Cardiol 167: 2719-2723, 2012.

157. Herzog CA, Ma JZ and Collins AJ: Comparative survival of dialysis patients in the United States after coronary angioplasty, coronary artery stenting, and coronary artery bypass surgery and impact of diabetes. Circulation 106: 2207-2211, 2002.

158. Szczech LA, Reddan DN, Owen WF, Racz M, Jones RH and Hannan EL: Differential survival after coronary revascularization procedures among patients with renal insufficiency. Kidney Int 60: 292-299, 2001.

159. Koyanagi T, NisIDHa H, Kitamura M, Endo M, Koyanagi H, Kawaguchi M, Magosaki N, Suiyoshi T and Hosoda S: Comparison of clinical outcomes of coronary artery bypass grafting and percutaneous transluminal coronary angioplasty in renal dialysis patients. Ann Thorac Surg 61: 1793-1796, 1996.

160. Podrid PJ: Pathophysiology and etiology of sudden cardiac arrest. UpToDate, 2020. https://www.uptodate.com/contents/pathophysiology-and-etiology-of-sudden-cardiac-arrest Accessed June 2, 2020.

161. Jadoul M, Thumma J, Fuller DS, Tentori F, Li Y, Morgenstern H, Mendekssohn D, Tomo T, Ethier J, Port F and Robinson BM: Modifiable practices associated with sudden death among hemodialysis patients in the dialysis outcomes and practice patterns study. Clin J Am Soc Nephrol 7: 765-774, 2012.

162. Pun PH, Lehrich RW, Smith SR and Middleton JP: Predictors of survival after cardiac arrest in outpatient hemodialysis clinics. Clin J Am Soc Nephrol 2: 491-500, 2007.

163. Kudenchuk PJ, Stuart R, Husain S, Fahrenbruch C and Eisenberg M: Treatment and outcome of out-of-hospital cardiac arrest in outpatient health care facilities. Resuscitation 97 97-102, 2015.

164. Makar MS and Pun HP: Sudden cardiac death among hemodialysis patients. Am J Kidney Dis 69: 684-695, 2017.

165. Huikuri HV, Castellanos A and Myerburg RJ: Sudden death due to cardiac arrhythmias. N Engl J Med 345: 1473-1482, 2001.

166. Bayes de Luna A, Coumel P and Leclercq JF: Ambulatory sudden cardiac death: Mechanisms of production of fatal arrhythmia on the basis of data from 157 cases. Am Heart J 117: 151-159, 1989.

167. Ohtake T, Kobayashi S, Moriya H, Negishi K, Okamoto K, Maesato K and Saito S: High prevalence of occult coronary artery stenosis in patients with chronic kidney disease at the initiation of renal replacement therapy: An angiographic examination. J Am Soc Nephrol 16: 1141-1148, 2005.

168. Yamada S, Ishii H, Takahashi H, Aoyama T, Morita Y, Kasuga H, Kimura K, Ito Y, Takahashi R, Toriyama T, et al: Prognostic value of reduced left ventricular ejection fraction at start of hemodialysis therapy on cardiovascular and all-cause mortality in end-stage renal disease patients. Clin J Am Soc Nephrol 5: 1793-1798, 2010.

169. Kalantar-Zadeh K, Block G, Humphreys MH and Kopple JD: Reverse epidemiology of cardiovascular risk factors in maintenance dialysis patients. Kidney Int 63: 793-808, 2003.
170. Bleyer AJ, Hartman J, Brannon PC, Reeves-Daniel A, Satko SG and Russell G: Characteristics of sudden death in hemodialysis patients. Kidney Int 69: 2268-2273, 2006.

171. Mangrum AJ, Lin D, Dimarco JP, Bolton WK and Mangrum JM: Sudden cardiac death and left ventricular function in hemodialysis patients. Heart Rhythm 2 (Suppl): S33, 2005.

172. Keller SP and Halperin HR: Cardiac arrest: The changing incidence of ventricular fibrillation. Curr Treat Options Cardiovasc Med 17: 392, 2015

173. Bonato FO, Lemos MM, Cassiolato JL and Canziani ME Prevalence of ventricular arrhythmia and its associated factors in nondialyzed chronic kidney disease patients. PLoS One 8: e66036, 2013

174. Wan C, Herzog CA, Zareba W and Szymkiewicz SJ: Sudden cardiac arrest in hemodialysis patients with wearable cardioverter defibrillator. Ann Noninvasive Electrocardiol 19: 247-257, 2014

175. Lafrance JP, Nolin L, Senecal L and Leblanc M: Predictors and outcome of cardiopulmonary resuscitation (CPR) calls in a large haemodialysis unit over a seven-year period. Nephrol Dial Transplant 21: 1006-1012, 2006.

176. Charytan DM, Foley R, McCullough PA, Rogers JD, Zimetbaum P, Herzog CA and Tumlin JA; MiD Investigators and Committees: Arrhythmia and sudden death in hemodialysis patients: Protocol and baseline characteristics of the monitoring in dialysis study. Clin J Am Soc Nephrol 11: 721-734, 2016.

177. Roy-Chaudhury P, Tumlin JA, Koplan BA, Costea AI, Kher V, Williamson D, Pokhariyal S and Charytan DM; MiD investigators and committees: Primary outcomes of the Monitoring in Dialysis Study indicate that clinically significant arrhythmias are common in hemodialysis patients and related to dialytic cycle. Kidney Int 93: 941-951, 2018

178. Ganesh SK, Stack AG, Levin NW, Hulbert-Shearon T and Port FK: Association of elevated serum $\mathrm{PO}(4), \mathrm{Ca} \times \mathrm{PO}_{(4)}$ product, and parathyroid hormone with cardiac mortality risk in chronic hemodialysis patients. J Am Soc Nephrol 12: 2131-2138, 2001.

179. Herzog CA: Cardiac arrest in dialysis patients: Approaches to alter an abysmal outcome. Kidney Int Suppl 63: S197-S200, 2003.

180. Pun PH, Smarz TR, Honeycutt EF, Shaw LK, Al-Khatib SM and Middleton JP: Chronic kidney disease is associated with increased risk of sudden cardiac death among patients with coronary artery disease. Kidney Int 76: 652-658, 2009.

181. Diaconu C: Treatment of diabetes in patients with heart failure. In: Proceedings of the 3rd International Conference on Interdisciplinary Management of Diabetes Mellitus and its Complications-Diabetes mellitus as cardiovascular disease. INTERDIAB, Bucharest, pp170-177, 2017.

182. Parekh RS, Plantinga LC, Kao WHL, Meoni LA, Jaar BG, Fink NE, Powe NR, Coresh J and Klag MJ: The association of sudden cardiac death with inflammation and other traditional risk factors. Kidney Int 74: 1335-1342, 2008

183. Drechsler C, Krane V, Winkler K, Dekker FW and Wanner C: Changes in adiponectin and the risk of sudden death, stroke, myocardial infarction, and mortality in hemodialysis patients. Kidney Int 76: 567-575, 2009.

184. Domanski MJ, Zipes DP and Schron E: Treatment of sudden cardiac death. Current understandings from randomized trials and future research directions. Circulation 95: 2694-2699, 1997.

185. Agarwal R, Sinha AD, Pappas MK, Abraham TN and Tegegne GG: Hypertension in hemodialysis patients treated with atenolol or lisinopril: A randomized controlled trial Nephrol Dial Transplant 29: 672-681, 2014.

186. Tangri N, Shastri S, Tighiouart H, Beck GJ, Cheung AK, Eknoyan $\mathrm{G}$ and Sarnak MJ: $\beta$-Blockers for prevention of sudden cardiac death in patients on hemodialysis: A propensity score analysis of the HEMO Study. Am J Kidney Dis 58: 939-945, 2011.

187. Beaubien ER, Pylypchuk GB, Akhtar J and Biem HJ: Value of corrected QT interval dispersion in identifying patients initiating dialysis at increased risk of total and cardiovascular mortality. Am J Kidney Dis 39: 834-842, 2002.

188. Di Iorio B, Torraca S, Piscopo C, Sirico ML, Micco LD, Pota A, Tartaglia D, Berardino L, Morrone LF and Russo D: Dialysate bath and QTc interval in patients on chronic maintenance hemodialysis: Pilot study of single dialysis effects. J Nephrol 25: 653-660, 2012. 
189. Pun PH, Horton JR and Middleton JP: Dialysate calcium concentration and the risk of sudden cardiac arrest in hemodialysis patients. Clin J Am Soc Nephrol 8: 797-803, 2013.

190. Timofte D, Ionescu D, Medrihan L, Mandita A, Rasina A and Damian L: Vascular calcification and bone disease in hemodialysis patients assessment, association and risk factors. Nephrol Dialysis Transplantation 22: 325-326, 2007.

191. Timofte D, Dragos D, Balcangiu-Stroescu AE, Tanasescu MD, Balan DG, Raducu L, Tulin A, Stiru O and Ionescu D: Abdominal aortic calcification in predialysis patients: Contribution of traditional and uremia-related risk factors. Exp Ther Med 20: 97-102, 2020.

192. Kim ED and Parekh RS: Calcium and sudden cardiac death in end-stage renal disease. Semin Dial 28: 624-635, 2015.

193. Di Lullo L, Rivera R, Barbera V, Bellasi A, Cozzolino M, Russo D, De Pascalis A, Banerjee D, Floccari F and Ronco C: Sudden cardiac death and chronic kidney disease: From pathophysiology to treatment strategies. Int J Cardiol 217: 16-27, 2016.
194. Flythe JE and Brunelli SM: The risks of high ultrafiltration rate in chronic hemodialysis: Implications for patient care. Semin Dial 24: 259-265, 2011

195. Flythe JE, Kimmel SE and Brunelli SM: Rapid fluid removal during dialysis is associated with cardiovascular morbidity and mortality. Kidney Int 79: 250-257, 2011.

196. Mendoza JM, Bayes LY, Sun S, Doss S and Schiller B: Effect of lowering dialysate sodium concentration on interdialytic weight gain and blood pressure in patients undergoing thrice-weekly in-center nocturnal hemodialysis: A quality improvement study. Am J Kidney Dis 58: 956-963, 2011.

197. Jefferies HJ, Burton JO and McIntyre CW: Individualised dialysate temperature improves intradialytic haemodynamics and abrogates haemodialysis-induced myocardial stunning, without compromising tolerability. Blood Purif 32: 63-68, 2011.

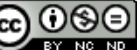

This work is licensed under a Creative Commons Attribution-NonCommercial-NoDerivatives 4.0 International (CC BY-NC-ND 4.0) License. 